\title{
Implikasi Yuridis Peraturan Pemerintah Pengganti Undang-Undang Nomor 2 Tahun 2017 tentang Perubahan Atas Undang-Undang Nomor 17 Tahun 2013 tentang Organisasi Kemasyarakatan di Indonesia
}

\author{
Dian Kus Pratiwi* \\ DOI: https://doi.org/10.22304/pjih.v4n2.a4
}

\begin{abstract}
Abstrak
Pemerintah Indonesia menganggap terdapat organisasi masyarakat yang memiliki kegiatan bertentangan dengan Pancasila. Undang-Undang Organisasi Kemasyakatan di Indonesia juga dinilai belum memadai sebagai sarana untuk mencegah meluasnya ideologi yang bertentangan dengan Pancasila. Hal ini menjadi salah satu alasan pemerintah mengeluarkan Peraturan Pemerntah Pengganti Undang-Undang Nomor 2 Tahun 2017 tentang Perubahan atas Undang-Undang Nomor 17 Tahun 2013 tentang Organisasi Kemasyarakatan (Perpu Ormas). Perlu dikaji lebih lanjut mengenai alasan dikeluarkannya Perpu dan implikasi yuridisnya. Artikel ini memberi gambaran secara rinci tentang situasi yang dikaji dalam perspektif norma Hukum Tata Negara. Hadirnya Perpu ini bukan merupakan upaya pemerintah untuk membungkam kebebasan masyarakat untuk berserikat dan berkumpul, namun pembatasan ruang gerak ormas ini penting mengingat Indonesia telah sepakat berideologi Pancasila.. Dengan demikian, implikasi yuridis dari Perpu ini adalah kewajiban dari Dewan Perwakilan Rakyat untuk membahas sebagai pelaksanaan fungsi check and balances antara presiden dan DPR dalam pembuatan produk hukum di Indonesia serta menghindari kewenangan luar biasa presiden. DPR perlu mencermati materi muatan Perpu terutama mengenai asas contrarius actus sebagai dasar ditiadakannya proses pengadilan dalam proses pembubaran organisasi masyarakat.
\end{abstract}

Kata kunci: contrarius actus, kegentingan memaksa, ormas, pancasila, perpu.

\section{The Juridicial Implication of Government Regulation in Lieu of Law Number 2 Year 2017 on Amendment of Law Number 17 Year 2013 on Community Organization in Indonesia}

\begin{abstract}
The Government of Indonesia has assumed that there is a mass organization which carries conflicting agendas with Pancasila. Law on Mass Organization is also thought to be ineffective in suppressing the widespread ideology which contradicts the Pancasila. This situation is among the reason on why the government issued Government Regulation in Lieu of Law Number 2 Year 2017 on the Revision of Law on Mass Organization, thus further research is needed on the reasoning behind the promulgation and its juridical implication. This article will provide detailed explanation on the situation as seen from Constitutional Law. The promulgation of this government regulation in lieu of law does not intend to silence

PADJADJARAN Jurnal IImu Hukum Volume 4 Nomor 2 Tahun 2017 [ISSN 2460-1543] [e-ISSN 2442-9325]

* Dosen Fakultas Hukum Universitas Islam Indonesia, Jl. Tamansiswa No 158 Yogyakarta, dian.pratiwi.sh@gmail.com, S.H. (Universitas Sebelas Maret), M.H. (Universitas Gadjah Mada).
\end{abstract}


the freedom of assembly and association, nevertheless the limitation is needed to ensure the standing of Pancasila. Therefore, the juridical implications from this government regulation in lieu of law is the obligation of the House of Representative to hold further discussion with the President under its check and balance function when formulating any law regulation as well as to prevent any misconduct of the President's extraordinary power. The House of Representative must also monitor the content of government regulation in lieu of law, especially the contrarius actus principle as the basis of the erasure of litigation process during the dissolution of mass organization.

Keywords: contrarius actus, urgency, mass organization, Pancasila, government regulation in lieu of law.

\section{A. Pendahuluan}

Indonesia merupakan negara hukum yang berdemokrasi. Beberapa faktor penting penegak negara demokrasi yakni negara yang bediri dalam konsepsi hukum, adanya masyarakat madani, insfrastruktur politik yang meliputi partai politik dan organisasi masyarakat (Ormas), dan juga adanya pers yang bebas serta bertanggung jawab. Salah satu poin penting dalam negara demokrasi yakni adanya jaminan kebebasan berserikat yang terefleksikan oleh pendirian Ormas. Ormas ini diharapakan sebagai wadah masyarakat dalam rangka kebebasan berpendapat, berserikat, berkumpul.

Menteri Koordinator bidang Politik, Hukum, dan Keamanan menyampaikan bahwa Ormas di Indonesia saat ini mencapai 344.039 Ormas, yang telah beraktifitas di segala bidang kehidupan, baik dalam tingkat nasional maupun di tingkat daerah, harus diberdayakan dan dibina. ${ }^{1}$ Sehingga dapat memberikan kontribusi positif bagi pembangunan nasional. Namun di sisi lain jika kita menilik lebih lanjut, pada kenyataannya saat ini terdapat kegiatan-kegiatan ormas yang bertentangan dengan Pancasila dan Undang-Undang Dasar Negara Republik Indonesia 1945 (UUD 1945), yang merupakan ancaman terhadap eksistensi bangsa dengan telah menimbulkan konflik di masyarakat. Sebagai contoh organisasi masyarakat Hizbur Tahrir Indonesia yang dalam kegiatannya mengusung sebuah konsep negara khilafah atau negara islam, yang kemudian oleh pemerintah dianggap mengancam kelangsungan bentuk Negara Kesatuan Republik Indonesia (NKRI).

Atas pertimbagan tersebut, pemerintah di bawah kepemimpinan Presiden Joko Widodo dan Wakil Presiden Jusuf Kalla mengeluarkan Peraturan Pemerintah Pengganti Undang-Undang Republik Indonesia Nomor 2 Tahun 2017 tentang Perubahan atas Undang-Undang Nomor 17 Tahun 2013 tentang Organisasi Kemasyarakatan (Perpu Ormas). Undang-Undang Nomor 17 Tahun 2013 tentang

\footnotetext{
Kementerian Komunikasi dan Informasi (Kominfo), “Pemerintah Keluarkan Perppu No. 2 Tahun 2017 tentang Perubahan atas Undang-Undang Ormas",

https://kominfo.go.id/index.php/content/detail/10094/pemerintah-keluarkan-perppu-no-22017-tentangperubahan-atas-undang-undang-ormas/0/artikel_gpr, diakses tanggal 22 Agustus 2017
} 
Organisasi Kemasyarakatan (UU Ormas 2013) dirasa tidak lagi memadai sebagai sarana untuk mencegah meluasnya ideologi yang bertentangan dengan Pancasila dan UUD 1945, baik dari aspek substantif terkait dengan norma, larangan dan sanksi serta prosedur hukum yang ada. Beberapa alasan utamanya antara lain pertama, tidak terwadahinya asas hukum administrasi contrario actus yaitu asas hukum bahwa lembaga yang mengeluarkan izin atau yang memberikan pengesahan adalah lembaga yang seharusnya mempunyai wewenang untuk mencabut atau membatalkannya. Kedua, pengertian tentang ajaran dan tindakan yang bertentangan dengan Pancasila dirumuskan secara sempit yaitu hanya sebatas pada ajaran Atheisme, Marxisme dan Lininisme, padahal sejarah Indonesia membuktikan bahwa ajaran-ajaran lain juga bisa dan bertentangan dengan Pancasila.

Pemerintah menganggap Perpu ini sebagai payung hukum untuk menjamin, memberdayakan dan membina ormas. Di sini terdapat asas contrario actus, maka lembaga mana yang memberikan izin dan mengesahkan Ormas itu diberikan hak dan kewenangan untuk mencabut izin itu pada saat Ormas yang bersangkutan melanggar ketentuan yang berlaku pada saat diberikan izin. Di pihak lain, dengan dikeluarkannya Perpu Ormas ini menjadi memanas manakala pemerintah selanjutnya mengeluarkan kebijakan pembubaran ormas Hizbur Tahrir Indonesia.

Dikeluarkannya Perpu Ormas ini menarik untuk diteliti mengenai implikasi yuridis Perpu terhadap kebebasan berserikat dan berkumpul. Dengan demikian, rumusan masalah yang akan dikaji di dalam artikel ini adalah bagaimana implikasi yuridis Perpu Ormas di Indonesia?

\section{B. Kajian Peraturan Pemerintah Pengganti Undang-Undang sebagai Hukum Darurat Negara}

Perpu adalah peraturan perundang-undangan yang ditetapkan oleh Presiden dalam hal ihwal kegentingan yang memaksa. Hal ini secara konstitusional diatur dalam UUD 1945 Pasal 22, yang berbunyi:

(1) Dalam hal ihwal kegentingan yang memaksa, Presiden berhak menetapkan peraturan pemerintah sebagai pengganti undangundang.

(2) Peraturan pemerintah itu harus mendapat persetujuan DPR dalam persidangan berikutnya.

(3) Jika tidak mendapat persetujuan maka peraturan pemerintah itu harus dicabut.

Definisi Perpu dijabarkan kembali pada pada Pasal 1 Angka 4 Undang-Undang Nomor 12 Tahun 2011 tentang Pembentukan Peraturan Perundang-undangan (UU P3).

Kedudukan Perpu dalam hierarki peraturan perundang-undangan diterangkan dalam Pasal 7 ayat (1) UU P3 adalah sebagai berikut: 
1. Undang-Undang Dasar Negara Republik Indonesia Tahun 1945;

2. Ketetapan Majelis Permusyawaratan Rakyat;

3. Undang-Undang/Peraturan Pemerintah Pengganti Undang-Undang;

4. Peraturan Pemerintah;

5. Peraturan Presiden;

6. Peraturan Daerah Provinsi; dan

7. Peraturan Daerah Kabupaten/Kota.

Pasal 7 ayat (2) UU P3 menyatakan, hierarki di atas menunjukkan urutan kekuatan hukum dari setiap peraturan perundang-undangan tersebut.

Dalam jenis dan hierarki peraturan perundang-undangan di Indonesia, kedudukan Perpu sama derajatnya (sejajar) dengan undang-undang (UU). Sehingga materi muatan Perpu adalah sama dengan materi muatan UU, Namun berbeda dalam hal proses pembentukannya. Perpu merupakan inisiasi Presiden dan dikeluarkan dengan syarat adanya hal ihwal kegentingan yang memaksa. Menurut Maria Farida Indrati Soeprapto, ${ }^{2}$ karena Perpu ini merupakan peraturan pemerintan (PP) yang mengagantikan kedududukan UU, maka materi muatannya adalah sama dengan materi muatan dari UU. Hal ini juga sama dikemukakan oleh Bagir Manan, ${ }^{3}$ yang dimaksud dengan pengganti UU adalah bahwa materi muatan Perpu merupakan materi muatan UU, atau dalam keadaan biasa (normal) harus diatur dengan UU.

Perpu mempunyai kesederajatan dengan UU, karena materi muatannya semestinya diatur dengan undang-undang, namun karena suatu kegentingan yang memaksa terpaksa diatur dengan Perpu. ${ }^{4}$ Pemahaman mengenai 'hal ihwal kegentingan yang memaksa' diartikan juga dengan 'kepentingan yang mendesak' dengan kriteria sebagai berikut: ${ }^{5}$

1. Hanya dikeluarkan dalam hal ihwal kegentingan yang memaksa;

2. Perpu tidak boleh mengatur mengenai hal-hal yang diatur dalam UUD atau Ketetapan Majelis Permusyawaratan Rakyat (TAP MPR);

3. Perpu tidak boleh mengatur mengenai keberadaan dan tugas wewenang lembaga negara. Tidak boleh ada Perpu yang dapat menunda atau menghapuskan kewenangan lembaga negara; dan

4. Perpu hanya boleh mengatur ketentuan UU yang berkaitan dengan penyelenggaraan pemerintahan.

2 Maria Farida Indrati Soeprapto, Ilmu Perundang-Undangan Dasar-Dasar dan Perkembangannya, Yogyakarta: Kanisius, 1998, hlm. 131.

3 Bagir Manan, Dasar-Dasar Perundang-Undangan Indonesia, Cetakan Pertama, Jakarta: Ind-Hill-Co, 1992, hlm. 50.

4 Bagir Manan dan Kuntana Magnar, Beberapa Masalah Hukum Tata Negara Indonesia, Bandung: Alumni, 1993, hlm. 150-151.

$5 \quad$ Ibid., hlm. 151. 
Penjelasan mengenai frasa 'kegentingan memaksa' antara lain dapat ditemukan di Pertimbangan Hukum dalam Putusan Mahkamah Konstitusi (MK) Nomor 138/PUU-VII/2009 tentang Permohonan Pengujian Peraturan Pemerintah Pengganti Undang-Undang Nomor 4 Tahun 2009 tentang Perubahan Atas UndangUndang Nomor 30 Tahun 2002 tentang Komisi Pemberantasan Tindak Pidana Korupsi terhadap UUD 1945 yang diucapkan pada hari Senin, 8 Februari 2010. Dalam putusan tersebut, MK menafsirkan frasa 'kegentingan memaksa' yang dimaksud konstitusi sebagai prasyarat perlu dibuat sebuah Perpu adalah:

1. Ada kebutuhan mendesak untuk menyelesaikan masalah hukum secara cepat berdasarkan UU; dan

2. UU yang dibutuhkan belum ada sehingga terjadi kekosongan hukum atau ada UU tetapi tidak memadai.

Kekosongan hukum tersebut tidak dapat diatasi dengan cara membuat UU melalui prosedur biasa karena memerlukan waktu yang cukup lama sedangkan keadaan yang mendesak tersebut perlu kepastian untuk diselesaikan.

Selain itu mekanisme pembentukan Perpu dibentuk dan ditandatangani oleh Presiden. Setelah diundangkan, Perpu harus diajukan ke Dewan Perwakilan Rakyat (DPR) dalam persidangan yang berikut, dalam bentuk pengajuan Rancangan Undang-Undang (RUU) tentang penetapan Perpu menjadi UU. Pembahasan RUU tentang penetapan Perpu menjadi UU dilaksanakan melalui mekanisme yang sama dengan pembahasan RUU. DPR hanya dapat menerima atau menolak Perpu. Jika Perpu ditolak DPR, maka Perpu tersebut tidak berlaku, dan Presiden mengajukan RUU tentang Pencabutan Perpu tersebut, yang dapat pula mengatur segala akibat dari penolakan tersebut.

Dari penjelasan singkat terkait pembentukan Perpu maupun materi muatan Perpu, maka dapat disimpulkan bahwa Perpu merupakan produk hukum yang dibuat pada saat negara dalam keadaan darurat atau dapat disebut sebagai 'peraturan darurat'. Dalam keadaan darurat ini Hukum Tata Negara yang berlaku dalam sebuah negara merupakan hukum yang bersifat darurat atau Hukum Tata Negara darurat (staatnoodrecth). Menurut Herman Sihombing, Hukum Tata Negara Darurat merupakan hukum tata negara dalam keadaan bahaya atau darurat, yaitu sebagai rangkaian pranata dan wewenang negara secara luar biasa dan istimewa, untuk dalam waktu sesingkat-singkatnya dapat menghapuskan keadaan darurat atau bahaya yang mengancam, ke dalam kehidupan biasa menurut perundangundangan dan hukum umum dan biasa. ${ }^{6}$

Dalam istilah staatnoodrecht, negara berada dalam keadaan darurat sehingga hukum yang berlaku adalah hukum yang memang dimaksudkan untuk berlaku

6 Herman Sihombing, Hukum Tata Negara Darurat di Indonesia, Jakarta: Djambatan, 1996, hlm. 26. 
dalam keadaan darurat. ${ }^{7}$ Mengacu pada hal tersebut maka Perpu Ormas juga dapat dikatakan sebagai peraturan darurat yang dikeluarkan oleh Presiden dengan pembatasan bahwa Perpu Ormas dikeluarkan dalam hal ihwal kegentingan yang memaksa. Terkait dengan hal ihwal kegentingan yang memaksa, tidak hanya terbatas pada keadaan yang mengandung suatu kegentingan atau ancaman, tetapi termasuk juga didalamnya kebutuhan yang yang dipandang mendesak. Dalam praktik hal ihwal kegentingan yang memaksa ini merupakan penafsiran subjektif Presiden sehingga dapat dikatakan sebagai hukum darurat (sucbjecktif staatnoodrecth). ${ }^{8}$ Perpu tersebut menegaskan sikap pemerintah yang tidak main-main dalam menjaga Indonesia. Sebelumnya, Presiden Joko Widodo juga mengeluarkan pernyataan yang keras yakni akan 'gebuk' organisasi yang coba-coba menganggu Indonesia.

Penerbitan Perpu Ormas ini tidak lepas dari adanya situasi kegentingan yang memaksa dan situasi darurat. Hal ini merupakan syarat untuk mengeluarkan sebuah Perpu. Pada bagian penjelasan Perpu secara jelas mengutip putusan Mahkamah Konstitusi International Covenant on Civil and Political Rights (ICCPR). Dalam penjelasannya, dapat diartikan bahwa yang dimaksud dengan 'hal ihwal kegentingan yang memaksa' adalah ancaman terhadap masa depan kehidupan bangsa Indonesia dan keberadaan NKRI. Hal inilah yang kemudian melatarbelakangi Presiden untuk menggunakan haknya dalam mengeluarkan sebuah hukum darurat dalam bentuk Perpu.

Kemudian, keadaan darurat yang melatarbelakangi dikeluarkannya Perpu Ormas ini merupakan keadaan darurat yang dapat mengancam kedaulatan negara berdasarkan Pancasila dan UUD 1945, antara lain kegiatan ormas tertentu yang telah melakukan tindakan permusuhan, antara lain: ucapan, pernyataan, sikap atau aspirasi baik secara lisan maupun tertulis, melalui media elektronik ataupun tidak memakai media elektronik, yang dapat menimbulkan kebencian baik terhadap kelompok tertentu maupun terhadap mereka yang termasuk ke dalam penyelenggara negara.

Sebagai hukum darurat yang bersifat subjektif, maka lahirnya Perpu Ormas ini dianggap sebagai hak Presiden dalam membentuk sebuah hukum yang berlaku dalam negara keadaan darurat. Sifat subjektifitas yang terkandung dalam Perpu ini merupakan hak yang dimiliki oleh Presiden dan dijamin secara konstitusional dalam Pasal 22 ayat (1) UUD 1945. Hal inilah yang dapat diartikan Presiden diberikan hak prerogratif yang dapat digunakan untuk diambil dalam keadaan darurat. Meskipun demikian sebagai negara hukum, hak subjektif presiden ini harus diuji apakah

Kabul Arifin, Sutjipto, dan Sujiwo, Peraturan Pemerintah Pengganti UU tentang Keadaan Bahaya sebaga Hukum Tata Negara Darurat Positif dan Latar Belakangnya, Jakarta: Bappit Pusat, Permata, 1960, hlm. 28-29.

8 Jimly Asshiddiqie, Hukum Tata Negara Darurat, Jakarta: Raja Grafindo Persada, 2007, hlm. 23. 
memang benar produk hukum tersebut layak dikeluarkan dalam keadaan darurat. Hal inilah yang menjadi perdebatan apakah Perpu Ormas memang memenuhi unsur negara dalam keadaan darurat atau 'kegentingan yang memaksa'. Perdebatan mengenai definisi negara dalam keadaan darurat inilah yang menarik untuk diperdebatkan oleh wakil rakyat di DPR sebagai indikator apakah Perpu tersebut memang layak dikeluarkan dalam keadaan darurat atau tidak.

Dalam bahasa hukum Indonesia, perkataan 'keadaan darurat' pernah dibedakan dari pengertian 'keadaan bahaya'. Semula dalam Undang-Undang Nomor 74 Tahun 1957 tentang Pencabutan "Regeling of de Staat van Oorlog en van beleg" dan Penetapan "Keadaan Bahaya" dan dalam peraturan-peraturan sebelumnya, keadaan darurat dibedakan dari keadaan perang. Karena pengaruh istilah yang dipergunakan dalam peraturan di zaman Hindia Belanda, yaitu Regering of de Staat van Oorlog en van Beleg Tahun 1939, perkataan keadaan darurat dan keadaan bahaya dibedakan datu sama lain. Staat van oorlog diterjemahkan menjadi keadaan perang, sedangkan staat van beleg diterjemahkan sebagai keadaan darurat. Dengan demikian perkataan keadaan bahaya tidak mencakup pengertian keadaan perang ataupun sebaliknya. Oleh karena itu dalam UU di atas, keadaan bahaya itu dibedakan dalam dua tingkatan pengertian, yaitu keadaan darurat dan keadaan perang seperti yang tercermin dalam rumusan Pasal 1 ayat (1) seperti telah dikutipkan di atas. ${ }^{9}$

Tidak selalu keadaan darurat itu bersifat militer atau berkaitan dan memerlukan peranan militer dalam menjalankan fungsi-fungsi pemerintahan dalam keadaan darurat tersebut. Misalnya, keadaan darurat yang bersifat administratif berupa keadaan darurat keuangan atau financial emergency ataupun keadaan darurat biasa disebut sebagai welfare emergency, ataupun keadaan darurat yang terjadi dalam negara yang terkena bencana alam maupun konflik sosial, yang sama sekali tidak mutlak untuk memerlukan peranan penguasa militer. Oleh karena itu, kewenangan presiden untuk menetapkan Perpu juga tidak selalu harus mempersyaratkan pemberlakuan keadaan darurat lebih dulu. ${ }^{10}$

Dalam konteks Indonesia, beberapa syarat formil yang harus dipenuhi untuk pemberlakuan suatu keadaan darurat atau keadaan yang berbahaya (state of emergency, state of exception, etate de siege) adalah sebagai berikut:

a. Pernyataan atau deklarasi berlakunya kedadaan darurat itu harus dituangkan dalam bentuk tertentu, yaitu dengan keputusan presiden, sedangkan peraturan materiil yang diperlukan dalam darurat tersebut dapat dituangkan dalam bentuk Perpu sebagaimana dimaksud oleh UUD 1945.

b. Pejabat yang secara konstitusional berwenang untuk menetapkan dan mengatur dalam keadaan darurat itu hanya presiden, bukan pejabat yang lain.

$9 \quad$ Ibid., hlm. 13.

10 Ibid, hlm. 80. 
c. Peraturan Presiden (Perpres) dan Perpu yang dimaksud di atas disahkan dan ditandatangani oleh presiden serta diundangkan dalam lembaran negara sebagaimana mestinya. ${ }^{11}$

d. Perpu hendaklah menentukan dengan jelas ketentuan-ketentuan UU apa saja yang dikesampingkan oleh berlakunya Perpu tersebut.

e. Perpres yang dimaksud harus menentukan dengan jelas wilayah hukum berlakunya dalam wilayah Indonesia. Misalnya apakah Perpu itu berlaku untuk seluruh wilayah nasional atau hanya berlaku di daerah tertentu saja, seperti hanya di provinsi tertentu atau di kabupaten tertentu.

f. Perpu dan Perpres dimaksud di atas harus pula menentukan dengan pasti lama masa berlakunya keadaan darurat tersebut. Jika pembatasan semacam itu tidak ditegaskan, berarti Perpres atau Perpu tersebut hanya berlaku selama masa persidangan DPR sampai dengan dibukanya kembali masa persidangan berikutnya sebagaimana dimaksud dalam Pasal 22 UUD 1945.

g. Segera setelah diberlakukan, Perpu harus diajukan kepada DPR untuk mendapatkan persetujuan sebagaimana mestinya. Jika dalam masa persidangan yang bersangkutan, DPR tidak atau belum menyatakan persetujuanya, Perpu itu harus dinyatakan dicabut oleh presiden.

Semua hal yang diuraikan tersebut di atas berlaku sebagai prinsip-prinsip hukum dalam kondisi negara berada dalam keadaan darurat (state of emergency, etat de siege, state of exception). Sementara itu, dalam keadaan normal (normal state), norma hukumnya berlaku seperti biasa, yaitu berlaku untuk umum dan bersifat tetap. Demikian pula dengan keberadaan lembaga-lembaga hukum dan lembaga-lembaga penyelenggara kekuasaan negara pada umumnya, semuanya diharuskan berfungsi atau menjalankan kekuasaanya sebagaimana seharusnya menurut konstitusi dan peraturan perundang-undangan yang mengaturnya.

UU Ormas 2013 dirasa tidak lagi memadai sebagai sarana untuk mencegah meluasnya ideologi yang bertentangan dengan Pancasila dan UUD 1945, baik dari aspek substantif terkait dengan norma, larangan dan sanksi serta prosedur hukum yang ada. Hal ini yang dianggap sebagai situasi darurat. Dengan demikian, melalui Perpu Ormas dibuatlah perluasan definisi mengenai paham yang bertentangan dengan Pancasila. Dalam Penjelasan Pasal 59 ayat (4) UU Ormas menyatakan: "Yang dimaksud dengan 'ajaran yang bertentangan dengan Pancasila' adalah ajaran ateisme, komunisme/marxisme-leninisme". Sedangkan dalam Penjelasan Pasal 59 ayat (4) huruf c Perpu Ormas menyatakan: "Yang dimaksud dengan 'ajaran yang bertentangan dengan Pancasila' adalah ajaran ateisme, komunisme/marxismeleninisme, atau paham lain yang bertujuan mengganti/mengubah Pancasila dan UUD 1945".

11 Lihat Pasal 82 huruf d dan e Undang-Undang Nomor 12 Tahun 2011 tentang Pembentukan Peraturan Perundang-undangan (UU P3). 
Penambahan frasa "atau paham lain yang bertujuan mengganti/mengubah Pancasila dan UUD 1945" dapat diartikan sebagai perluasan dari ajaran-ajaran yang dapat mengancam ideologi dan dasar negara kita. Namun demikian, penambahan frasa dan definisinya masih terkesan bias, hal ini dikarenakan hingga saat ini belum ada parameter mengenai paham yang bertentangan dengan Pancasila dan kaitannya dengan kehidupan demokrasi itu seperti apa. Hal tersebut di satu sisi jelas memang secara efektif dapat menindak Ormas yang hendak merongrong Indonesia, namun di sisi lain dikhawatirkan merupakan upaya pemerintah untuk membungkam Ormas yang berseberangan dengan pemerintah dikarenakan tidak adanya parameter/indikator mengenai paham yang bertentangan dengan pemerintah.

Hal tersebut berkaitan dengan berkembangnya paham radikal yang tidak terlepas dari keberadaan Ormas radikal dan Ormas yang menjual paham-paham yang bertentangan dengan Pancasila. Hal tersebut ditengarai dari banyaknya kasus persekusi yang dilakukan oleh beberapa Ormas yang kemudian diikuti dengan ujaran-ujaran kebencian yang menjalar di media sosial yang kemudian dapat menjadi sarang untuk berkembangnya teroris melalui literatur internet dan media sosial dari andil beberapa Ormas. Oleh karena hal ini, dalam kondisi yang sangat mendesak, terdapat beberapa Ormas radikal, Ormas yang menjual ide-ide pahampaham yang bertentangan dengan NKRI dan Pancasila, sehingga pemerintah harus melakukan tindakan yang cepat. Hal inilah yang kemudian menjadi dalih untuk 'kegentingan yang memaksa' dikeluarkannya Perpu Ormas di mana pemerintah dalam menanggapi kondisi tersebut berdaulat secara politik dan bergerak cepat dalam rangka melindungi bangsa dari Ormas yang ingin merongrong kedaulatan NKRI. Dalih atas 'kegentingan yang memaksa' tersebut dapat dikaitkan dengan ciri keadaan mendesak (emergency) dan terdapatnya unsur ancaman yang membahayakan (dangerous threat). ${ }^{12}$

Senada dengan hal tersebut, eksistensi Pancasila dan UUD 1945 memang harus dipertahankan, apalagi menyangkut bentuk NKRI. Hal ini mengingat bahwa ideologi dan dasar negara UUD 1945 maupun bentuk negara kesatuan ini merupakan citacita perjuangan bangsa Indonesia. Sehingga setiap Ormas yang dinilai merongrong eksistensi ideologi Pancasila maupun NKRI patut di berikan pengawasan dari pemerintah. Namun hal ini juga harus mendasarkan pada indikator/parameter yang jelas apa definisi maupun kriteria dari dari ajaran-ajaran yang dapat mengancam ideologi dan dasar negara kita.

Asas hukum administrasi yang menjadi landasan yuridis diterbitkannya Perpu ini adalah asas contrario actus yakni, lembaga yang yang mengeluarkan izin atau

12 Eka Padmahanta, "Problemantika Penerbitan Perppu No. 2 Tahun 2017 dan Lika Liku Perppu di Indonesia", http://www.kompasiana.com/ekapadma25/problematika-penerbitan-perppu-ormas-dan-lika-liku-perppudi-indonesia 5970adb94fc4aa4bcd62b6c2, diakses tanggal 22 Agustus 2017. 
memberikan pengesahan kepada ormas, memiliki wewenang untuk mencabut atau membatalkannya. Substansi Perpu ini adalah adanya kewenangan pemerintah untuk memberikan sanksi terhadap Ormas yang dianggap tidak sejalan dengan semangat Pancasila dan UUD 1945. Bahkan, kepada pengurusnya bisa dikenai dengan sanksi tindak pidana

\section{Implikasi Yuridis Peraturan Pemerintah Pengganti Undang-Undang Nomor 2 Tahun 2017 tentang Perubahan Undang-Undang Nomor 17 Tahun 2013 tentang Organisasi Masyarakat di Indonesia}

Sebagai peraturan darurat, Perpu mengandung beberapa batasan, pertama, Perpu hanya dikeluarkan dalam hal ihwal kegentingan yang memaksa. Penentuan hal ihwal kegentingan yang memaksa ini tentu menjadi subjektifitas presiden. Kedua, sebagai peraturan darurat maka seyognya Perpu yang dikeluarkan presiden juga memiliki limitasi keberlakuannya. Dalam arti lain Perpu tersebut memiliki jangka waktu terbatas. Pembatasan jangka waktu dan persetujuan DPR ini mengandung berbagai makna: ${ }^{13}$

1. Kewenangan membuat Perpu memberikan kekuasaan luar biasa kepada presiden. Kekuasaan luar biasa ini harus dikendalikan untuk menghindari penyalahgunaan kekuasaan dengan mempergunakan Perpu sebagai sarana;

2. Materi muatan Perpu merupakan materi muatan UU. Oleh karena itu harus diajukan kepada DPR untuk mendapat persetujuan DPR menjadi UU;

3. Perpu mencerminkan suatu keadaan darurat. Keadaan darurat merupakan pembenaran untuk misalnya menyimpang prinsip-prinsip negara berdasarkan atas hukum atau prinsip-prinsip negara berkonstitusi.

Menurut Jimly Asshiddiqie, syarat materiil untuk penetapan perpu, yaitu (a) adanya kebutuhan yang mendesak untuk bertindak atau reasonable necessity; (b) waktu yang tersedia terbatas atau terdapat kegentingan waktu; dan (c) tidak tersedia alternatif lain diperkirakan tidak akan dapat mengatasi keadaan, sehingga penetapan Perpu merupakan satu-satunya cara untuk mengatasi keadaan tersebut. $^{14}$

Dari beberapa hal yang telah diuraikan di atas, maka penetapan Perpu Ormas perlu mendapat persetujuan oleh DPR dalam jangka waktu 1 (satu) tahun setelah Perpu tersebut ditetapkan. Hal ini dikarenakan beberapa hal; pertama, untuk menghindari kewenangan luar biasa presiden yang dapat menetapkan Perpu dalam prespektif subjektifitas presiden dalam keadaan negara dalam keadaan darurat (kegentingan memaksa). Prespektif subjektif presiden inilah yang perlu mendapat pengujian dari DPR apakah memang layak keadaan negara dalam keadaan darurat

13 Bagir Manan dan Kuntana Magnan, Loc.cit.

14 Jimly Asshidiqie, Perihal Undang-Undang, Jakarta: Rajawali Press, 2010, hlm. 213. 
(kegentingan memaksa) dan perlu menetapkan Perpu. Hal ini untuk menghindari penyalahgunaan kekuasaan presiden yang luar biasa.

Penetapan Perpu ini dengan pertimbangan bahwa negara berkewajiban melindungi kedaulatan NKRI berdasarkan Pancasila dan UUD 1945, dan pelanggaran terhadap asas dan tujuan organisasi kemasyarakatan yang didasarkan Pancasila dan UUD 1945 merupakan perbuatan yang sangat tercela dalam pandangan moralitas bangsa Indonesia terlepas dari latar belakang etnis, agama, dan kebangsaan pelakunya. Selain UU Ormas mendesak untuk segera dilakukan perubahan karena belum mengatur secara komprehensif mengenai keormasan yang bertentangan dengan Pancasila dan UUD 1945 sehingga terjadi kekosongan hukum dalam hal penerapan sanksi yang efektif.

Kedua, pembahasan Perpu Ormas oleh DPR juga menyangkut materi yang diatur oleh Perpu itu sendiri. Hal ini terkait dengan materi muatan Perpu merupakan materi muatan UU. Di mana Perpu Ormas merupakan perubahan UU Ormas, yang didalamnya terdapat beberapa penambahan maupun penghapusan dari pasalpasal materi muatan yang ada dalam UU Ormas. Hal inilah yang perlu dicermati oleh DPR apakah materi yang ada dalam Perpu Ormas ini telah sesuai atau belum. Jangan sampai terjadi overlapping materi yang diatur dalam Perpu ini ataupun ada muatan yang seharusnya diatur namun dihapuskan oleh Perpu Ormas.

Ketiga, pembahasan Perpu Ormas ini sebagai bukti pelaksanaan fungsi check and balances antara presiden dan DPR dalam pembuatan produk hukum di Indonesia. Mengingat Perpu memiliki derajat yang sama dengan UU maka dalam proses persetujuan Perpu menjadi UU, dalam hal presiden menetapkan Perpu maka peran DPR untuk membahas dan mengontrol berlakunya Perpu itu masih harus difungsikan sehingga pemberlakuan keadaan darurat itu sendiri tetap dikendaikan dan diawasi oleh para wakil rakyat di DPR.

Dari latar belakang tersebutlah maka DPR berwenang melakukan pembahasan dan pengujian terhadap Perpu yang dikeluarkan oleh presiden apakah sesuai dengan aturan perundang-undangan yang ada maupun sistem ketatanegaraan di Indonesia. Sehingga implikasi yang timbul adalah dalam masa sidang DPR selanjutnya DPR harus membahas dan menguji Perpu tersebut. Jika disetujui maka Perpu tersebut diundangkan menjadi UU mengantikan UU Ormas, namun jika tidak disetujui oleh DPR konsekuensi yang timbul yakni dicabut dan tidak berlaku lagi.

\section{Implikasi terhadap Kebebasan Berserikat dan Berkumpul Warga Negara}

Dikeluarkannya Perpu Ormas tentu banyak yang mendukung, dan ada yang lantang menolak. Semua memiliki argumentasi sendiri-sendiri. Pada saatnya nanti, DPR akan merespon Perpu ini apakah diterima sebagai UU atau ditolak. Perpu menegaskan maksud dan tujuan untuk membedakan dan melindungi Ormas yang konsisten dengan tujuan berdirinya berdasarkan Pancasila dan UUD 1945 tanpa 
mengancam kebebasan berkumpul dan berserikat dalam negara demokrasi di Indonesia. Hanya saja, tidak ada kebebasan yang mutlak, karena setiap kebebasan pasti memiliki sisi kewajiban. Negara juga tidak boleh membiarkan ancaman terhadap setiap hasil demokrasi dengan dalih demokrasi. Pemeliharaan dan penjagaan setiap hasil kesepakatan yang demokratis harus tegas baik secara hukum, maupun dengan cara lain yang dimungkinkan sebagai sebuah negara.

Dengan Perpu ini pemerintah mengindikasikan adanya kegentingan yang memaksa sehingga harus dibentuk sebuah Perpu dalam melindungi NKRI dari ancaman ormas yang bertentangan dengan Pancasila dan mengantisipasi internalisasi paham radikalisme di tubuh Ormas. Namun demikian, secara kontekstual muncul respon balik mengapa Perpu ini harus dikeluarkan. Sebagian kalangan menganggap kehadiran Perpu ini berpotensi mengancam kewajiban negara untuk menghormati dan melindungi Hak Asasi Manusia (HAM) yang dijamin di dalam Undang-Undang Nomor 39 Tahun 1999 tentang Hak Asasi Manusia (UU HAM), khususnya hak atas keyakinan politik (Pasal 23 ayat (1), hak untuk berpendapat (Pasal 23 ayat (2) jo. Pasal 25), hak untuk berserikat/berkumpul (Pasal 24 ayat (1) dan (2), dan hak atas keadilan (Pasal 17).

Menurut hemat penulis, hadirnya Perpu ini dalam konteks negara Indonesia sebagai negara hukum yang demokratis tidak perlu disikapi sebagai upaya pemerintah untuk membungkam kebablasan masyarakat untuk berserikat dan berkumpul dalam negara demokrasi di Indonesia ini. Hal ini mengingat negara masih memberikan jaminan, masyarakat dapat membetuk sebuah Ormas dengan tujuan maupun paham yang tidak bertentangan dengan Pancasila sebagai dasar Negara Indonesia. Pembatasan ruang gerak Ormas ini penting, mengingat bangsa Indonesia telah sepakat berlandaskan ideologi Pancasila, dengan dasar negara UUD 1945 dan bentuk negara kesatuan, jangan sampai cita-cita pendiri bangsa ini hancur dikarenakan ancaman dari Ormas yang bertentangan dengan cita-cita tersebut. Sehingga secara normatif jika Perpu ini disyahkan menjadi UU maka dapat digunakan sebagai dasar hukum dalam pengaturan Ormas di Indonesia.

Namun di sisi lain, pengaturan dalam Perpu Ormas ini perlu ditinjau ulang terkait asas contrario actus dan beberapa pasal terkait pencabutan izin terhadap Ormas yang bertentangan dengan UU. Asas contrarius actus menyatakan bahwa badan atau pejabat Tata Usaha Negara (TUN) yang menerbitkan keputusan TUN dengan sendirinya juga berwenang membatalkan. Hal tersebut secara eksplisit dijelaskan dalam Penjelasan Pasal 61 ayat (3) Perpu Ormas yang menyatakan bahwa:

"Yang dimaksud dengan "penjatuhan sanksi administratif berupa pencabutan surat keterangan terdaftar dan pencabutan status badan hukum" adalah sanksi yang bersifat langsung dan segera dapat dilaksanakan oleh Menteri Dalam Negeri atau Menteri Hukum dan Hak 
Asasi Manusia terhadap Ormas yang asas dan kegiatannya nyata-nyata mengancam kedaulatan Negara Kesatuan Republik Indonesia berdasarkan Pancasila dan Undang-Undang Dasar Negara Kesatuan Republik Indonesia 1945, sehingga Pemerintah berwenang melakukan pencabutan.

Pencabutan surat keterangan terdaftar atau pencabutan status badan hukum Ormas sudah sesuai dengan asas contrarius actus, sehingga pejabat yang berwenang menerbitkan surat keterangan/surat keputusan juga berwenang untuk melakukan pencabutan."

Dengan diterbitkannya Perpu Ormas ini, mekanisme pembubaran dapat dikatakan lebih ringkas serta 'tanpa harus melalui jalur pengadilan' dibandingkan dengan UU Ormas.

Berdasarkan UU Ormas, perlu diketahui bahwa Ormas memiliki kewajiban sebagaimana diatur dalam Pasal 21, serta larangan-larangan yang tidak boleh dilakukan oleh Ormas sebagaimana Pasal 59. Hal tersebut tidak ada perubahan signifikan dengan pengaturan yang terdapat dalam Perpu Ormas, kecuali mengenai perluasan definisi paham yang bertentangan dengan Pancasila dalam Penjelasan Pasal 59. Dalam UU Ormas, pemerintah atau pemerintahan daerah sesuai dengan lingkup tugas dan kewenangannya menjatuhkan sanksi administratif kepada Ormas yang melanggar ketentuan kewajiban serta larangan dalam Pasal 21 dan Pasal 59. Sebelum menjatuhkan sanksi administratif, pemerintah atau pemerintah daerah melakukan upaya persuasif terlebih dahulu. Sanksi administratif tersebut terdiri atas:

1. Peringatan tertulis;

a. Peringatan tertulis kesatu;

b. Peringatan tertulis kedua; dan

c. Peringatan tertulis ketiga.

2. Penghentian bantuan dan/atau hibah;

3. Penghentian sementara kegiatan; dan/atau

4. Pencabutan surat keterangan terdaftar atau pencabutan status badan hukum.

Pembubaran Ormas ini terkait dengan sanksi administratif pencabutan surat keterangan terdaftar atau status badan hukum ormas. Sanksi administratif pencabutan surat keterangan terdaftar atau status badan hukum ormas merupakan sanksi yang dijatuhkan setelah ormas tidak mematuhi/mengindahkan sanksi-sanksi administratif sebelumnya. Sanksi pencabutan status badan hukum dilaksanakan oleh menteri yang menyelenggarakan urusan pemerintahan di bidang hukum dan hak asasi manusia.

Dalam UU Ormas, pencabutan status badan hukum Ormas dilaksanakan dalam jangka waktu paling lama 30 hari terhitung sejak tanggal diterimanya salinan putusan pembubaran Ormas yang telah memperoleh kekuatan hukum tetap. 
Pencabutan status badan hukum Ormas diumumkan dalam Berita Negara Republik Indonesia. Ini berarti, untuk dapat melakukan pencabutan tersebut, harus terlebih dahulu ada putusan pembubaran Ormas yang telah memperoleh kekuatan hukum tetap, setelah itu baru pemerintah dapat menjatuhkan sanksi pencabutan status badan hukum. Adapun tata cara pembubaran Ormas adalah sebagai berikut:

1. Permohonan pembubaran ormas berbadan hukum, sebagaimana disebutkan di atas, diajukan ke pengadilan negeri oleh kejaksaan hanya atas permintaan tertulis dari menteri yang menyelenggarakan urusan pemerintahan di bidang hukum dan hak asasi manusia.

2. Permohonan diajukan kepada ketua pengadilan negeri sesuai tempat domisili hukum Ormas dengan disertai bukti penjatuhan sanksi administratif oleh pemerintah atau pemerintah daerah.

3. Dalam hal permohonan tidak disertai bukti penjatuhan sanksi administratif, permohonan pembubaran Ormas berbadan hukum tidak dapat diterima.

4. Setelah permohonan diajukan, pengadilan negeri menetapkan hari sidang dalam jangka waktu paling lama 5 (lima) hari kerja terhitung sejak tanggal pendaftaran permohonan. Surat pemanggilan sidang pemeriksaan pertama harus sudah diterima secara patut oleh para pihak paling lambat 3 (tiga) hari sebelum pelaksanaan sidang.

5. Dalam sidang pemeriksaan ormas sebagai pihak termohon diberi hak untuk membela diri dengan memberikan keterangan dan bukti di persidangan.

6. Permohonan pembubaran Ormas harus diputus oleh pengadilan negeri dalam jangka waktu paling lama 60 hari terhitung sejak tanggal permohonan dicatat dan harus diucapkan dalam sidang terbuka untuk umum. Jangka waktu ini dapat diperpanjang paling lama 20 hari atas persetujuan Ketua Mahkamah Agung.

7. Pengadilan negeri menyampaikan salinan putusan pembubaran Ormas kepada pemohon, termohon, dan Menteri Hukum dan HAM dalam jangka waktu paling lama 7 (tujuh) hari terhitung sejak tanggal putusan diucapkan dalam sidang terbuka untuk umum.

Jika kita bandingkan dengan mekanisme pembubaran Ormas berdasarkan Perpu, pemerintah atau pemerintah daerah sesuai dengan lingkup tugas dan kewenangannya masih tetap menjatuhkan sanksi administratif kepada ormas yang melanggar ketentuan kewajiban serta larangan dalam Pasal 21 dan Pasal 59. Namun perbedaannya terdapat tambahan larangan dalam Pasal 51 serta dalam Penjelasan Pasal 59 mengenai perluasan definisi paham yang bertentangan dengan Pancasila. Perbedaan lainnya adalah Ormas yang melanggar ketentuan yang terdapat di atas dijatuhi sanksi administratif dan/atau sanksi pidana.

Perbedaan sanksi administratif mengenai peringatan tertulis adalah tidak adanya tahapan hingga 3 peringatan tertulis. Peringatan tertulis sebagaimana dimaksudkan hanya diberikan satu (1) kali dalam jangka waktu 7 (tujuh) hari kerja 
sejak tanggal diterbitkan peringatan. Terkait sanksi administratif dalam perpu tersebut terdiriatas:

1. Peringatan tertulis;

2. Penghentian kegiatan; dan/atau

3. Pencabutan surat keterangan terdaftar atau pencabutan status badan hukum.

Kemudian dalam hal Ormas tidak mematuhi peringatan tertulis sebagaimana dimaksudkan di atas, menteri dan menteri yang menyelenggarakan urusan pemerintahan di bidang hukum dan hak asasi manusia sesuai dengan kewenangan 'menjatuhkan sanksi penghentian kegiatan'. Apabila dalam hal Ormas tidak mematuhi sanksi penghentian kegiatan sebagaimana dimaksudkan, menteri dan menteri yang menyelenggarakan urusan pemerintahan di bidang hukum dan HAM sesuai dengan kewenangannya melakukan pencabutan surat keteragan terdaftar atau pencabutan status badan hukum. Dalam hal ini, 'tidak perlu ada putusan pengadilan yang memiliki kekuatan hukum tetap' guna memberikan legalitas dalam hal pembubaran Ormas yang berbadan hukum. Pencabutan surat keterangan terdaftar oleh Menteri Dalam Negeri dan pencabutan status badan hukum oleh Menteri Hukum dan HAM di sini berarti sekaligus merupakan upaya pembubaran.

Dari perbedaan terkait pembubaran Ormas dalam UU Ormas maupun Perpu Ormas tersebutlah yang memunculkan perdebatan. Hal ini karena dalam Perpu Ormas pemerintah seakan dapat menggunakan kewenangannya untuk membubarkan Ormas yang dirasa bertentangan dengan pemerintah tanpa adanya putusan pengadilan terlebih dahulu. Padahal apabila menilik fungsi dari proses peringatan tertulis hingga pemeriksaan pengadilan dalam UU Ormas yang lama terdapat sebuah makna asas praduga tak bersalah terhadap Ormas yang dinilai bertentangan dengan UU. Ormas masih memiliki diberi hak untuk membela diri dengan memberikan keterangan dan bukti di persidangan. Proses peradilan inilah yang kemudian dihilangkan dan dinilai mencederai nilai demokrasi maupun keadilan dalam Perpu Ormas tersebut.

Pelaksanaan asas contrario actus dinilai memberikan ruang kesewenangwenangan pemerintah dalam mengawasi maupun melakukan pembubaran Ormas yang dirasa tidak sejalan dengan pemerintah. Terbukti dengan keluarnya Perpu Ormas ini berdampak langsung terhadap pembubaran Ormas Hizbut Tahrir Indonesia yang tidak lama setelah dikeluarkannnya Perpu Ormas tersebut dicabut surat keterangan terdaftar oleh Menteri Dalam Negeri dan pencabutan status badan hukum oleh Menteri Hukum dan HAM yang sekaligus merupakan upaya pembubaran Ormas tersebut tanpa adanya proses pengadilan.

\section{Penutup}

Perpu Ormas perlu pembahasan oleh DPR dalam jangka waktu satu tahun setelah Perpu tersebut di tetapkan. Hal ini dikarenakan beberapa hal; pertama untuk 
menghindari kewenangan luar biasa presiden yang dapat menetapkan Perpu dalam prespektif subjektifitas presiden pada negara dalam keadaan darurat (kegentingan memaksa). Kedua, pembahasan Perpu Ormas oleh DPR juga menyangkut materi yang diatur oleh Perpu itu sendiri. Jangan sampai terjadi overlapping materi yang diatur dalam Perpu ini ataupun ada muatan yang seharusnya diatur namun dihapuskan. Ketiga, pembahasan Perpu Ormas sebagai bukti pelaksanaan fungsi check and balances antara presiden dan DPR dalam pembuatan produk hukum di Indonesia. Peran DPR untuk membahas dan mengontrol berlakunya Perpu itu masih harus difungsikan sehingga pemberlakuan keadaan darurat itu sendiri tetap dikendaikan dan diawasi oleh para wakil rakyat di DPR.

Dari beberapa alasan tersebut, maka DPR berwenang melakukan pembahasan dan pengujian Perpu Ormas pada masa sidang DPR selanjutnya. Jika disetujui maka Perpu tersebut diundangkan menjadi UU mengantikan UU Ormas, namun jika tidak disetujui oleh DPR konsekuensi yang timbul yakni dicabut dan tidak berlaku lagi.

Hadirnya Perpu ini dalam konteks negara Indonesia sebagai negara hukum yang demokratis, tidak perlu disikapi sebagai upaya pemerintah untuk membungkam kebebasan masyarakat untuk berserikat dan berkumpul. Hal ini mengingat negara masih memberikan jaminan bahwa masyarakat dapat membetuk sebuah organisasi masyarakat dengan tujuan maupun paham yang tidak bertentangan dengan Pancasila sebagai dasar negara Indonesia. Pembatasan ruang gerak Ormas ini penting mengingat bangsa Indonesia telah sepakat berlandaskan ideologi Pancasila dengan dasar negara UUD 1945 dan bentuk negara kesatuan. Jangan sampai citacita pendiri bangsa ini hancur karena ancaman dari Ormas yang bertentangan dengan cita-cita tersebut. Sehingga secara normatif jika Perpu ini disahkan menjadi UU maka dapat digunakan sebagai dasar hukum dalam pengaturan organisasi mayarakat di Indonesia.

Dalam pengujian dan pembahasan Perpu Ormas oleh DPR perlu pencermatan terkait dengan urgency dari Perpu apakah telah sesuai memenuhi unsur kegentingan yang memaksa dan perlu dibuat aturan hukum dalam Perpu. Secara normatif jika Perpu ini disahkan menjadi UU maka dapat digunakan sebagai dasar hukum dalam pengaturan organisasi mayarakat di Indonesia. DPR perlu meninjau ulang asas contrarius actus dalam Perpu Ormas dan perlu tidaknya keterlibatan lembaga peradilan dalam proses pembubaran Ormas. Jika Perpu Ormas tidak disetujui sebagai UU, maka seyogyanya tetap memaksimalkan implementasi dari UU Ormas yang ada.

\section{Daftar Pustaka \\ Buku}

Bagir Manan, Dasar-Dasar Perundang-Undangan Indonesia, Cetakan Pertama, IndHill-Co, Jakarta, 1992. 
Bagir Manan dan Kuntana Magnar, Beberapa Masalah Hukum Tata Negara Indonesia, Alumni, Bandung, 1993.

Herman Sihombing, Hukum Tata Negara Darurat di Indonesia, Djambatan, Jakarta, 1996.

Kabul Arifin, Sutjipto, dan Sujiwo, Peraturan Pemerintah Pengganti UU tentang Keadaan Bahaya sebaga Hukum Tata Negara Darurat Positif dan Latar Belakangnya, Bappit Pusat, Permata, Jakarta, 1960.

Jimly Asshiddiqie, Hukum Tata Negara Darurat, Raja Grafindo Persada, Jakarta, 2007.

Perihal Undang-Undang, Rajawali Press, Jakarta, 2010.

Maria Farida Indrati Soeprapto, Ilmu Perundang-Undangan Dasar-Dasar dan Perkembangannya, Kanisius, Yogyakarta, 1998.

\section{Dokumen Lain}

Eka Padmahanta, "Problemantika Penerbitan Perppu No. 2 Tahun 2017 dan Lika Liku Perppu di Indonesia", diakses tanggal 22 Agustus 2017.

Kementerian Komunikasi dan Informasi (Kominfo), "Pemerintah Keluarkan Perppu No. 2 Tahun 2017 tentang Perubahan atas Undang-Undang Ormas", https://kominfo.go.id/index.php/content/detail/10094/pemerintah-keluarkanperppu-no-22017-tentang-perubahan-atas-undang-undang-ormas/0/artikel gpr, diakses tanggal 22 Agustus 2017

\section{Dokumen Hukum}

Undang-Undang Dasar Negara Republik Indonesia Tahun 1945

Undang-Undang Nomor 74 Tahun 1957 tentang Pencabutan "Regeling of de Staat van Oorlog en van Beleg" dan Penetapan "Keadaan Bahaya".Undang-Undang Nomor 39 Tahun 1999 tentang Hak Asasi Manusia.

Undang-Undang Nomor 12 Tahun 2011 tentang Pembentukan Peraturan Perundang-Undangan.

Undang-Undang Nomor 17 Tahun 2013 tentang Organisasi Masyarakat.

Peraturan Pemerintah Pengganti Undang-Undang Nomor 2 Tahun 2017 tentang Perubahan atas Undang-Undang Nomor 17 Tahun 2013 tentang Organisasi Masyarakat.

Putusan Mahkamah Konstitusi Nomor 138/PUU-VII/2009 tentang Permohonan Pengujian Peraturan Pemerintah Pengganti Undang-Undang Nomor 4 Tahun 2009 tentang Perubahan Atas Undang-Undang Nomor 30 Tahun 2002 tentang Komisi Pemberantasan Tindak Pidana Korupsi terhadap UUD 1945 yang diucapkan pada hari Senin, 8 Februari 2010. 